\title{
AS DINÂMICAS DA ARGUMENTAÇÃO REGIA NA DISSOLUÇÃO DA ORDEM DO TEMPLO E NA CRIAÇÃO DA ORDEM DE CRISTO. UM ESFORÇO INTERPRETATIVO (1307/08-1319)
}

\author{
THE DYNAMICS OF ROYAL ARGUMENTATION IN THE \\ DISSOLUTION OF THE TEMPLAR ORDER AND IN THE \\ CREATION OF THE ORDER OF CHRIST. AN INTERPRETATIVE \\ EFFORT (1307/08-1319)
}

Fabiano Fernandes Universidade Federal de São Paulo

Resumo: Sendo um clássico na historiografia sobre a Idade Média, o processo de dissolução da Ordem do Templo e de criação da Ordem de Cristo, normalmente, é tratado como algo que ocorreu de forma quase inteiramente harmônica em Portugal. Esse artigo vem questionar essa visão consolidada, em particular, na historiografia portuguesa, tomando para análise certas cartas de sentença, a documentação do Concílio de Vienne de 1311-1312, e parte da documentação relativa à criação da Ordem de Cristo. A não utilização indiscriminada da violência física ou do processo inquisitorial estrito-senso deveu-se muito mais a uma opção estratégica, em vez de necessariamente uma boa vontade inata do monarca ou da monarquia.

Palavras-chave: Ordem do Templo. Ordem de Cristo. Portugal Século XIV.

\begin{abstract}
As a classic in the historiography of the Middle Ages, the process of dissolution of the Order of the Temple and creation of the Order of Christ is usually treated as something that occurred almost entirely harmoniously in Portugal. This article questions this consolidated view, particularly in Portuguese historiography, by analyzing certain letters of judgment, the documentation of the Council of Vienne, 1311-1312, and part of the documentation relating to the creation of the Order of Christ. The indiscriminate non-use of physical violence or the strict sense-inquisitorial process owed much more to a strategic choice, rather than necessarily an innate goodness will of the monarch or the monarchy.
\end{abstract}

Keywords: Order of the Temple. Order of Christ. Portugal XIV century. 


\section{Introdução}

Recorrentemente as análises da relação Monarquia-Ordem de Cristo enfatizam o processo de "nacionalização" das ordens militares como fio explicativo da formação e desenvolvimento da nova Ordem monástico-militar ${ }^{1}$. Dessa forma, é comumente explorada a relação harmônica que teria existido entre a monarquia e os mestres de Cristo desde o processo de formação da Ordem, tomando como eixo explicativo o processo de centralização ${ }^{2}$. Esse fio narrativo está baseado em um discurso triunfalista e na ideologia nacionalista, conforme sugerido por Olival e Fernandes ${ }^{3}$. É comum a narrativa que trata da transição da Ordem do Templo ${ }^{4}$ para a Ordem de Cristo suavize os potenciais conflitos e turbulências no referido processo ${ }^{5}$.

Todavia certos estudos ${ }^{6}$ recomendam a revisão dessa perspectiva de transição pacífica assentada em parte da historiografia Ibérica ${ }^{7}$, afinal a intervenção nos bens

${ }^{1}$ CF. SILVA, Isabel Luísa Morgado de Sousa. A ordem de Cristo durante o mestrado de D. Lopo Dias de Sousa (1373?-1417), Militarium Ordinum Anacleta, vol.1, 1997, p. 5-126; Idem, A Ordem de Cristo (14171521). Militarium Ordinum Anacleta, vol. 6, 2002, p. 3-503. Cf. PIZARRO, Jose Augusto de Sotto Mayor. D. Dinis. Lisboa: Círculo dos Leitores, 2005.

${ }^{2}$ Para um balanço sobre as inter-relações entre construção da memória nacional e o estudo das ordens militares Cf. OLIVAL, Fernanda. As ordens militares na historiografia portuguesa (séculos XVI-XVIII): Notas de balanço. Penélope, 17, 1997, p.97-108.

${ }^{3}$ Uma tentativa de interpretação não inteiramente ancorada na noção de centralização pode ser encontrada em FERNANDES, Fabiano. O processo de formação da Ordem de Cristo e a conjuntura dos reinos ibéricos (C. 1250-1326). Revista Signum, vol. 13,2012, p. 134-160. Cf. Idem, O Reino de Deus e a espada do Rei: a formação do poder eclesiástico da Ordem de Cristo nas Comendas de Ega, Soure Redinha e Pombal na primeira metade do século XIV. vol 1 e 2.p.621. Tese (Tese de Doutorado em História). IFCS, Univ. Federal do Rio de Janeiro, RJ, 2005. Cf. OLIVAL, Fernanda. Op. cit.

${ }^{4}$ FERNANDES, Maria Cristina Ribeiro de Sousa. A Ordem do Templo em Portugal. Das origens à extinção. Tese (Dissertação de Doutoramento em História). Faculdade de Letras, Universidade do Porto, Porto, 2009.

${ }^{5}$ CF. GOMES, Saul António. Revista de História da Sociedade e da Cultura, Vol. 11, 2011, p.75-116. Vasconcelos, António Maria Falcão Pestana de. Nobreza e Ordens militares. Relações Sociais e de Poder. (séc. XIV a XVI). V.1. Tese (Dissertação de Doutoramento em História). Faculdade de Letras, Universidade do Porto, Porto, 2008, p.41-50. Apesar de Felipe de Oliveira enfatizar ordens diferentes em contexto cronológico distinto do aqui enfocado, a sua perspectiva sociológica no estudo das ordens militares leva a dar mais espaço para a questão dos conflitos. Indiretamente o referido autor acaba dando mais peso às alianças locais no processo de estruturação das Ordens militares. Dessa forma, nos sentimos particularmente inclinados à sua perspectiva, embora não seja exatamente a que adotamos nesse texto. Tendemos a acentuar mais a interdependência entre monarquia e Ordens militares no período de 1250 a 1320 do que simplesmente a ideia de pura e simples centralização. Os poderes se entrecruzavam em escalas diferentes que frequentemente se associavam de forma complementar no exercício do governo. Em alguns casos, as ordens militares no plano local estavam ligadas as aristocracias urbanas, que se constituíram ao longo dos séculos XII e XIII. Cf. OLIVEIRA, Luis Filipe. A coroa, os mestres e os comendadores. As ordens militares de Avis e de Santiago (1330-1449). Algarve: Universidade do Algarve, 2009.

${ }^{6}$ PORRO, Clive. Reassessing the Dissolution of the Templars: King Dinis and Their Suppression, Portugal. In: BURGETORF, Jochen; CRAWFORD, Paul F.; NICHOLSON, L. J. The Debate on the Trial of the Templars (1307-1314). London: Ashgate, 2010, p. 171-182.

${ }^{7}$ Podemos Tomar como exemplos significativos dessa tendência MARTÍNEZ, Carlos de Ayala. las órdenes militares y los procesos de afirmácion monárquica in Castilla y Portugal. Revista da Faculdade de Letras. 
templários seria, no mínimo, um atentado às liberdades da Igreja ${ }^{8}$, em uma época em que ainda era fresca a memória dos conflitos da monarquia com o clero os quais levaram aos acordos de 1289 e $1309^{9}$.

No primeiro item, buscaremos realizar uma redução de foco de análise, nesse plano a apropriação de parte dos bens templários pela monarquia em 1307-1308 obedece a uma lógica jurídico-política feudal, na qual os templários são tratados pelo rei como vassalos relapsos que deveriam, por isso, sofrer o confisco de terras, que a despeito de serem em tese isentas e ligadas à Santa Sé, teriam sido doadas pelos reis, logo sujeitas à intervenção pragmática do poder do suserano.

Dessa forma, o claro ataque a bens eclesiásticos era, de certa forma, transformado em um simples caso de justiça leiga, na qual a posição do rei era preponderante enquanto árbitro dos conflitos. Enfatizar o caráter feudal era uma estratégia para minimizar possíveis recursos dos membros da Ordem do Templo para a Santa Sé e uma forma de afastar o caso da Ordem do Templo das querelas entre monarquia e prelados que atravessaram boa parte do século XIII ${ }^{10}$. Logo, era preciso esvaziar o ataque à Ordem do

Tomo 2 V.2. XV-2, 1998, p. 1279-1312; Idem, La corona de Castilla Y La incorporacion de los maestrazgos. Militarium Ordinum Analecta, v. 1, 1997, p. 260-5.

${ }^{8}$ Mas, assim como Margarida Garcez Ventura -a despeito da autora tratar de uma época posterior à nossa-, preferimos aos conceitos de laicização e de secularização (os ambíguos) o conceito de identificação do poder temporal. A identificação do poder temporal não é incompatível com a sacralização dos atos do governo régio, fato que, levado às últimas consequências, justificava em parte as inúmeras interferências do poder régio nos assuntos considerados pelos clérigos como inerentes às liberdades eclesiásticas. Em outras palavras, o poder régio lucrava com as propostas teológicas que valorizavam o natural e o temporal e, ao mesmo tempo, esse poder fomentava a formulação jurídica do poder temporal por meio do direito romano. No entanto, simultaneamente, o rei imprimia um caráter sagrado em certos atos administrativos, fosse se opondo ou colaborando com o poder eclesiástico. VENTURA, Maria Garcez. Igreja e Poder no Século XV. Dinastia de Avis e Liberdades Eclesiásticas (1383-1450). Lisboa: Edições Colibri, 1997, p.29107. Todavia, consideramos o período dinonisino uma época em que os contornos da identificação do poder temporal ainda era relativamente frágil se comparado ao contexto da dinastia de Avis, levando em conta o peso da Igreja na administração central e na vida religiosa-política.

${ }^{9} \mathrm{O}$ acordo entre a monarquia e a Santa Sé buscava fechar um ciclo de afrontamentos diretos entre o poder real e os bispos em Portugal que manteve o reino sob interdito por cerca de 22 anos desde o reinado de Afonso III. No contexto desses conflitos, grande parte das Sés permaneceram vazias e boa parte dos bispos buscouasilo em Roma. Na chamada concordata de 1289 foram regulados particularmente assuntos que diziam respeito ao padroado sobre as igrejas, ou seja, o direito de apresentar clérigos para igrejas comuns e para igreja- catedrais (tal como bispos e cônegos), bem como da isenção de serviços públicos para o clero, da regulação do direito de silo, dos privilégios de foro, das inquirições, dentre outros. Na verdade os conflitos de jurisdição permaneceram em pauta nas reuniões antes e depois da concorda de 1289, tal como as de Santarém (1273-1274), as de Évora (1282), e nas Lisboa já referida (1289) e bem como nos acordos de D. Dinis com o clero em 1309. Cf. VENTURA, Leontina. D. Afonso III. Lisboa: Círculo dos leitores, 2006; PIZZARRO, José Augusto de Sotto Mayor. D. Dinis. Lisboa: Círculo de Leitores, 2005, p. 102 e 103.

${ }^{10}$ Cf. MARQUES, Maria Alegria Fernandes. O papado e Portugal no tempo de D. Afonso III (1245-1279). Tese (Tese de Doutorado em História). Faculdade de Letras, Universidade de Coimbra, Coimbra, 1990. 
Templo de seu foro religioso-eclesiástico, potencialmente sujeito à intervenção da jurisdição da hierarquia da Igreja.

No segundo item, dedicar-nos-emos a discutir como certas diretrizes do Concílio de Vienne 1311-1312 cooperaram para oferecer a oportunidade da criação da Ordem de Cristo por parte da monarquia portuguesa. Aqui as demandas do Concílio de Vienne de 1311-1312 serão particularmente enfatizadas, pois é o próprio discurso pontifício sobre a dissolução da Ordem que, de certa forma, delimita o escopo dos argumentos que servirão para a criação da futura Ordem de Cristo em 1319.

A ideia de cruzada foi tratada no âmbito pontifício, em fins do século XIII, como uma espécie de continuidade da reconquista, e essa associação oferecia aos reis Ibéricos um capital simbólico ${ }^{11}$ muito particular ${ }^{12}$, que de, certa forma, contribuía bastante para a criação da Ordem de Cristo em 1319. Aqui o discurso cruzadístico faz sentido, na medida em que tradicionalmente os reis Ibéricos tiveram uma liderança reconhecida e apoiada pelo papado na luta contra os muçulmanos ao menos desde o século XI. Entre um plano mais restrito, tal como o local/reino, e em outro mais amplo, tal como o da relação com o papado temos, como denominador comum, a ação da monarquia portuguesa, beneficiária indireta da criação da Ordem de Cristo em 1319.

${ }^{11}$ Como Jiménez, compreendemos que do ponto de vista ideológico é indubitável a força da noção de Reconquista desde a Alta Idade Média hispânica. Ao fim e ao cabo, conforme concordamos com o referido autor que uma ideologia não é necessariamente nem falsa nem verdadeira, precisa, sobretudo, ser operável, como de fato foi re-apropriada em diferentes contextos da História Ibérica. E efetivamente essa noção foi bastante influenciada a partir de fins do século XI pela noção de cruzada. Sobre La ideología de la Reconquista JIMÉNEZ, Manuel González. In: DUARTE, José Ignacio de la Iglesia; RODRIGUEZ, José Luis Martín. Memoria, mito y realidad en la historia medieval : XIII Semana de Estudios Medievales, Nájera, Atas de Congresso Nájera 2002, 2003, p. 151-170.

${ }^{12}$ Temos ciência da complexidade que o termo reconquista envolve no campo do debate historiográfico, bem como da polêmica gerada pela aplicação do termo cruzada a certas inciativas de guerra na Península Ibérica. Explorar isso com profundidade nesse texto nos levaria a desviar muito do seu tema central. Mas gostaríamos de afirmar que, nesse ponto, seguimos O'Callaghan para compreender que a noção de continuidade entre o reino de Astúrias e o antigo reino visigótico —e mais tarde nas demais monarquias ibéricas - fosse essa real ou virtual teve forte influência no imaginário sobre as conquistas. Logo, o conflito entre cristãos e muçulmanos na hispânia desde seus primórdios foi paulatinamente assumindo um ar de guerra religiosa, na medida em que a expansão do reino era uma forma de potencialmente expelir muçulmanos ou submeter territórios que outrora teriam estado sobre controle visigótico, em nome da fé e com a ajuda imaginada de Deus. A influência da ideia de cruzada sobre a de reconquista tem um histórico longo, mas podemos afirmar com base no referido autor que a anuência do papado, a concessão de bulas de cruzada, remissões de pecados na guerra, a ideia de martírio pela fé e o ato de assumir votos - práticas que surgem isoladamente ou em conjunto - permitem falar de uma influência da noção de cruzada na noção de reconquista. Nesse sentido a noção de cruzada é tanto uma prática quanto um topos diplomático manipulado por monarquias ou mesmo pelo papado para direcionar inciativas de guerra, legitimar ocupação de territórios e legitimar múltiplas interferências na expansão Ibérica. O'CALLAGHAN, Joseph. Reconquest and crusade in Medieval Spain. Philadelphia: University of Pennsylvania Press, 2004, p. 2-24. 
Propomos, como ideia central desse texto, que apesar de não ter ocorrido aparentemente violência física no tratamento dos freires templários e seus bens, nem por isso a transição de uma Ordem para outra foi necessariamente pacífica. Pois, se por um lado, a sistemática de apropriação dos bens em Portugal não seguiu o conjunto de argumentos tal qual proposto por Felipe, o Belo e seus agentes, isso se devia a uma escolha estratégica por parte do poder real em Portugal, que buscou argumentar com base no direito feudal como forma de afastar o problema do foro eclesiástico. Mas, ao mesmo tempo, esse discurso predominante no plano local/reino foi conciliado com uma visão cruzadística —discurso fundamental no âmbito da Cristandade —em voga particularmente no âmbito mediterrânico após a queda de Acre em $1291^{13}$. Esse último discurso teve na Península Ibérica como pano de fundo a luta de Castela contra os Merinidas, bem como a luta pelo controle do estreito de Gibraltar em fins do século XIII, conflitos que culminaram na batalha de Salado em $1340^{14}$.

\section{A estratégia jurídico-política feudal. Argumentação preponderante no plano local/reino a partir de um estudo de caso}

A região das vilas de Ega, Soure, Redinha e Pombal, após a Reconquista de Coimbra em 1064, passou gradualmente a sofrer a influência cristã nortenha. No entanto, paralelamente ao acréscimo da influência do poder Condal, tornou-se necessário conduzir o processo de uma cristianização mais afinada com a alcunhada reforma gregoriana. A indefinição dos limites das paróquias e a necessidade de implantá-las em localidades pouco povoadas tornavam a organização religiosa da região fronteiriça bastante fluida e de difícil controle por parte das forças cristãs ${ }^{15}$. Dois momentos foram particularmente marcantes para a implantação das estruturas eclesiásticas na região: no primeiro, iniciado em meados de 1064 (época de conquista definitiva da cidade de Coimbra) até 1128 (época do início da implantação da Ordem do Templo na região) foram preponderantes para a

\footnotetext{
${ }^{13}$ HOUSLEY, Norman. The Later Crusades. From Lyon to Alcazar. 1274-1580. New York: Oxford University Press, 1992, p. 267-90.

${ }^{14}$ Cf. O'CALLAGHAN, Joseph F. The Gibraltar crusade : Castile and the battle for the Strait. Philadelphia: University of Pennsylvania Press, 2011.

${ }^{15}$ Cf. FERNANDES, Fabiano. Terras, Poderes e conflitos: O Poder senhorial da Ordem do Templo e as vilas de Ega, Soure, Redinha, Pombal e Louriçal, 1129-1231. Dissertação (Dissertação de Mestrado em História), ICHF, Universidade Federal Fluminense, Niterói, 1997, p. 321.
} 
organização eclesiástica da região os conflitos entre os cristãos moçárabes e os partidários da reforma gregoriana. O segundo momento, iniciado a partir de 1128/29, foi marcado pela implantação das comendas templárias na região, que se desenvolveram ao longo dos séculos XII e XIII.

$\mathrm{Na}$ localidade onde se estruturaram as comendas templárias de Ega, Soure, Redinha e Pombal, havia uma forte presença da elite concelhia dos cavaleiros vilãos que tenderam, a partir de 1147, com a conquista de Lisboa, a direcionar ainda mais seus esforços para a valorização agrícola das localidades, em uma relação de colaboração como o poder senhorial templário.

Em fins do século XIII tanto o poder senhorial da Ordem do Templo quanto o seu poder eclesiástico estavam bem assentados na região que ainda possuía uma posição econômica estratégica, na medida em que a região estava próxima ao centro consumidor da cidade de Coimbra.

A despeito de uma relação comumente considerada de colaboração entre Ordem do Templo e poder monárquico o fato é que, possivelmente desde 1307, boa parte das comendas templárias começou a ser colocada sob controle direto de agentes régios, tal como as da região referida, possivelmente como reflexo indireto dos abalos que esta Ordem estava sofrendo por ocasião dos ataques de Felipe, o Belo, no reino da França. Podemos tomar como base para análise algumas cartas em que o rei D. Dinis se apropriava de um conjunto de importantes comendas da Ordem de Templo entre os anos 1307-1309.

Em uma carta elaborada em 1307 (lida em 1308 na região comendas de Ega, Soure, Redinha e Pombal) eram apresentados os princípios que justificavam a tomada de posse das possessões templárias nessas localidades. Era afirmado pelo procurador do rei que as:

(...) vilas e castelos de Soury e de Poonbal e sobrela Ega e sobrela Redinha com todos seus termhos e dereytos per raçom que (...) as ditas vilas castelos de Soury e de Poonbal e da Ega e da redinha eram meus [ do rei] e deviam a seer de dereyto e que os ditos maestre e freires tragiam como nom deviam e que como quer que os posuysem per alguu 
tenpo diziam que os posuyrom e os trouverom per mhas ofrença e per meu consentimento [do mesmo rei] $(. . .)^{16}$.

A concessão do foral de Soure, em 1111, pelo Conde D. Henrique e a sucessiva confirmação dos reis deste foral davam, até certo ponto, a base jurídica para tal argumentação. Recordava-se, assim, que a ligação com o poder régio (por meio da figura do pai do primeiro Rei) antecedera a concessão da vila de Soure e seu termo por D. Teresa, em 1128, para a Ordem dos Templários. Os detalhes desta argumentação estavam implícitos, mas buscava-se explicitar que a Ordem possuía de forma indevida os direitos sobre estas vilas com base no direito feudal, tendo em vista que os templários eram vassalos relapsos ${ }^{17}$, logo sobre as estruturas comendatárias, associadas às referidas vilas, seriam revertidas segundo esse ponto de vista para a realeza.

O direito de posse das vilas por parte da Ordem era colocado assim sob um alto nível de suspeição, a tal ponto que o rei chegava a sutilmente negar que havia necessariamente dado seu consentimento para esta posse ${ }^{18}$.

Mas, por ocasião da leitura da carta escrita em 1307, um aspecto não era tratado de forma sutil. A ideia de que a missão das ordens militares em geral, e da Ordem do Templo em particular, estava intimamente ligada ao serviço dos reis é algo explicitamente referido na carta de 1307 apresentada pelo porteiro régio João Amarante, em Soure, Redinha e Pombal em 1308 por meio de leitura pública nas referidas vilas. Nesta carta o rei diz que:

Entendo meu procurador que estamha sofrença queriam levar a mal e que os queriam trager posseus (...) feze-os chamar perdante a mha corte e deu por ouvidores deste feyto estando os ditos $\{\ldots\}^{19}$ os ditos areebispo e bispo e custodyo e mestre Johanne e Ruy nunis o dito meu procurador (...) demandava aos ditos mestres e freyres perdante $\{\ldots . .\}^{20}$ castelos e lugares $^{21}$.

Portanto, segundo a narrativa da carta de 1307, transladada em 1308, o mestre dos Templários e um número indeterminado de freires teriam sido chamados para serem

\footnotetext{
16 1308, junho, 29 e 30, Ega, Soure, Redinha e Pombal. I.A.N./T.T, Gav. 12, Mำ, Nº 19.

${ }^{17}$ Ibidem.

${ }^{18}$ Ibidem.

${ }^{19}$ Parte da fonte em mau estado. Impossível ler.

${ }^{20}$ Parte da fonte em mau estado. Impossível ler.

${ }^{21}$ 1308, junho, 29 e 30, Ega, Soure, Redinha e Pombal. I.A.N./T.T, Gav. 12, Mº, N $^{\circ} 19$.
} 
julgados pelos juízes do rei. Note-se que o motivo desta contenda seria a posse indevida destas vilas e não qualquer argumento de caráter explicitamente religioso, o principal argumento é jurídico-feudal pois é afirmado que “(...) as ditas villas e castelos de Soury e de Poobal e da redinha eram meus e deviam a seer de dereyto e que os ditos maestre e freires mhostragiam como nom deviam (...)"22. Em suma, as terras sob poder da Ordem haviam sido uma apropriação ilegal, sobretudo porque os freires não compareciam em conselho ${ }^{23}$.

Segundo esta mesma carta de 1307, transladada em 1308, o mestre e os freires teriam comparecido ao chamado inicial, mas teriam pedido tempo "a que ouvessem conçelho e que viesem com seus privilégios e com sas cartas que diziam que tynhamentontraçer" "24. Após esse pedido, os juízes teriam concedido um tempo de nove meses para que posteriormente os templários viessem responder sobre a posse das vilas ${ }^{25}$.

Algo nos chama a atenção nesta narrativa. Afinal, por que os templários estavam protelando a decisão final da situação das vilas? Causa-nos estranheza que as cartas, que, de certa forma, comprovavam a posse das citadas vilas por parte da Ordem, tais como os forais da região e a carta de doação de Soure e suas vilas, não tenham sido imediatamente mostradas em juízo.

É bem provável que esse pedido de tempo fosse uma estratégia para tentar evitar uma sentença que parecia de antemão definida de forma contrária aos interesses da Ordem. Ganhar tempo era algo fundamental, pois era necessário saber até que ponto a Ordem em Portugal poderia contar ou não com o apoio do mestre geral da Ordem do Templo ou mesmo do papado, em uma época em que a Ordem estava sendo fortemente atacada pelo rei de França e seus oficiais.

A carta de 1308 apresenta ainda um outro translado de uma outra carta de 23 de junho (provavelmente feita no mesmo ano de 1308, no Porto) que gostaríamos de destacar. Nesta carta se diz que o procurador régio veio perante os ditos ouvidores, acusando a Ordem de revelia ${ }^{26}$. O procurador régio teria pedido, então, que, devido à

\footnotetext{
${ }^{22}$ Como também é afirmado na carta onde o rei manda escrever que 1308, junho, 29 e 30, Ega, Soure, Redinha e Pombal. I.A.N./T.T, Gav. 12, $\mathrm{M}^{\circ} 7, \mathrm{~N}^{\circ} 19$.

${ }^{23}$ Ibidem; I.A.N./T.T. Livro dos Mestrados, fls. 143v-146v; .1314, abril (?), Coimbra. I.A.N./T.T. Livro dos Mestrados, fls.146v-148v; 1314, abril, Coimbra. I.A.N./T.T. Livro dos Mestrados, fls.146v-148v.

24 1308, junho, 29 e 30, Ega, Soure, Redinha e Pombal. I.A.N./T.T, Gav. 12, Mำ, Nº 19.

25 1308, junho, 29 e 30, Ega, Soure, Redinha e Pombal., Gav. 12, Mำ, No 19.

26 "O qual dia o dito meu procurador veo perdante os ditos ouvidores contnado per dabt'eles o feyto assi commo de suso dito he e acusando-os de revelya e dizendo que o tenpo lhys fora assinado a que veessem
} 
revelia, fossem entregues as vilas, castelos e lugares com seus termos vilas e pertenças para o rei ${ }^{27}$. É bem provável que a pressão do poder régio tenha se somado à notícia da prisão dos templários no reino da França ${ }^{28}$. O posicionamento ambíguo do papado não deve ter favorecido maiores resistências por parte do mestre e dos freires do Templo em Portugal. Mas esta relativa passividade parecia ter sido alcançada também por grande "pressão" exercida pelo poder régio por meio de seus agentes. Uma informação indireta talvez se coadune com esta nossa dedução.

Na carta de 23 de junho de 1308 (translada e lida na região das comendas enfocada nessa parte do texto), menciona-se que os juízes teriam recorrido a André Peris, que anteriormente se dizia procurador da Ordem e “(...) entom o dito André Periz veo perdante eles e disse que os nom querya defender e por moor avondamento de dereyto aguardando eles o dito maestre e freyres se veryam por sy ou per seus procuradores. "29. Esta passagem apresenta um indício bastante interessante, alguém que anteriormente fora procurador da Ordem desistiu de oficialmente defendê-la diante do rei, não era fácil se posicionar contra o rei e seus oficiais, sobretudo em um contexto de fragilização institucional da Ordem.

A manutenção do Templo enquanto Ordem religiosa já era considerada possivelmente por alguns em junho de 1308 como "causa perdida" ou, pelo menos, era esta impressão que se pode conjecturar a partir da leitura posterior desta carta transladada, algo que pode ter se refletido na hesitação de mestre e freires em comparecerem diante da justiça real ${ }^{30}$.

que era ya passado e que os ditos maestre e freyres nom pareciam per sy nen outrym por eles pedido de dereyto e de custume por revees e que em logo de revelia que me mandassem entregar as ditas vilas e castelos e logares com seus termos e villas e perteenças." 1308, junho, 29 e 30, Ega, Soure, Redinha e Pombal I.A.N./T.T, Gav. 12, $\mathrm{M}^{\circ} 7, \mathrm{~N}^{\circ} 19$.

${ }^{27}$ Ibidem.

${ }^{28}$ A prisão no reino de França ocorreu em 13 de outubro de 1307. Em 24 de outubro Jacques de Molay confessou que a cerimônia de recebimento dentro da Ordem passava por renegar a Cristo. No dia seguinte foi organizada uma assembleia de clérigos parisienses no dia na qual o referido mestre mais Geoffroy de Charnay e outros três dignatários também confessaram. Na ocasião foi redigido um documento com declarações do mestre da Ordem cujas cópias foram enviadas para os principais dirigentes de Cristandade.Em reação a atitude da monarquia francesa em 22 de novembro de 1307 Clement V ordenou escrevendo para todos os soberanos da Cristandade que os bens dos templários fossem sequestrados em nome da Igreja Romana com o objetivo de trazer o processo para a esfera da jurisdição da Igreja. Cf. THÈRY, Julien. Procès des templiers In: N. BÉRIOU, Ph. JOSSERAND. Dictionnaire européen desordres religieux militaries. Paris : Fayard, 2009, p. 743-750.

${ }^{29}$ 1308, junho, 29 e 30, Ega, Soure, Redinha e Pombal. I.A.N./T.T, Gav. 12, $\mathrm{M}^{\circ} 7, \mathrm{~N}^{\circ} 19$.

30 “(...) derom-nos per huum mês e mays e feçeromnos apregoar per as mhasaudiançasassy como e husso e custume da mha corte $E$ o dito maestre e freyres non veerom per sy nen per seus procuradores e aa petiçom do dito meu procurador por que nomveerom per synen per seus procuradores ao dito tenpo 
Na carta translada de 23 de junho de 1308, aponta-se que os ouvidores teriam dado o prazo para que alguém da Ordem comparecesse e "o dito maestre e freyres nom veerom per sy nen per seus procuradores (...)" 31 . Isto é apresentado como o motivo fundamental que levou à condenação e à tomada de posse das vilas.

$\mathrm{Na}$ sentença de 23 de junho de 1308, foi determinado que as vilas fossem entregues ao porteiro do rei, que por sua vez entregaria-a para Pero Martins de cryaçom do rei $^{32}$. E é justamente por ocasião da execução das sentenças que se procedeu, nas vilas em estudo, a leitura desses translados.

É interessante percebermos que a lista de testemunhos para essa última carta de 23 de junho de 1308 (da qual temos o translado) é bastante restrita. São citados como presentes na elaboração original desta carta os ouvidores no feito D. Martinho Arcebispo de Braga; D. João Bispo de Lisboa; D. Frei Custódio; Mestre João das leis; Rui Nunes. Cita-se ainda a presença de Afonso Raimundo, que, efetivamente, escreveu esta carta ${ }^{33}$. Ora, uma carta em que apenas constam como testemunhantes aqueles que decretaram as sentenças é um forte indício de que de, alguma forma, os templários foram excluídos ou se excluíram do processo.

Em relação a esta última carta, um comentário se faz ainda necessário. As duas autoridades eclesiásticas que maior interesse teriam, na região das comendas enfocadas, a saber: o bispado e o cabido da Sé de Coimbra não têm representantes para interferir na questão. A ausência de representantes das referidas instituições deve ser interpretada menos como uma iniciativa de escolher juízes mais isentos para julgar a questão do que o temor provável do poder régio de que qualquer apoio às pretensões régias fosse parcialmente condicionado à concessão de privilégios e terras nas localidades em questão.

Parece-nos instigante a coincidência entre os juízes e a lista de testemunhantes, sobretudo se levarmos em conta que esta questão era muito importante e envolvia interesses de outros senhorios eclesiásticos e concelhos. Não está claro se esta reunião pode ser considerada um ato de julgamento público ou apenas a reunião de eclesiásticos privados do rei. Em nenhum momento foi especificado nesta última carta qualquer motivo para a ausência de representantes da Ordem, isso do ponto de vista do discurso oficial era

julgaram-nos por revees e em logo de revelya (...)”. 1308, junho, 29 e 30, Ega, Soure, Redinha e Pombal. I.A.N./T.T, Gav. 12, $\mathrm{M}^{\circ} 7, \mathrm{~N}^{\circ} 19$. Os negritos são nossos.

${ }^{31}$ 1308, junho, 29 e 30, Ega, Soure, Redinha e Pombal. I.A.N./T.T, Gav. 12, Mำ, ${ }^{\circ} 19$.

32 1308, junho, 29 e 30, Ega, Soure, Redinha e Pombal. I.A.N./T.T, Gav. 12, $\mathbf{M}^{\circ} 7, \mathrm{~N}^{\circ} 19$.

33 1308, junho, 29 e 30, Ega, Soure, Redinha e Pombal. I.A.N./T.T, Gav. 12, Mำ, N 19. 
também uma forma de reforçar a justificativa de revelia e a consequente apropriação dos bens.

O não comparecimento dos templários a esta reunião pode até ter uma explicação bem simples e "pouco honrosa" devido ao fato de não terem sido comunicados do local e da época da realização de reuniões posteriores a 1307. Afinal, os relatos que analisamos foram feitos a pedido do rei e dos juízes por ele escolhidos ${ }^{34}$.

Estes relatos, além de comunicar a ausência dos templários ou de servirem como uma peça de um processo jurídico, têm como propósito também servir de subsídio para o processo de construção de uma determinada memória, em que prevalecem as informações favoráveis ao rei.

A sucessão de cartas transladadas em um único instrumento tinha também como objetivo mais imediato de serem lidas na região onde se procederia ao confisco dos bens. O translado e as leituras destas cartas as transformavam em peças fundamentais do cerimonial judiciário ${ }^{35}$, ou seja, no cerimonial judiciário o poder dominante busca alcançar seus objetivos mediante a produção de imagens, pela manipulação de símbolos dentro de um quadro cerimonial. A ideia básica que nutre a concepção de cerimonial judiciário é de que não é possível manter a dominação política exclusivamente pela força da coerção ou exclusivamente pela justificação racional. Tal como Balandier, compreendemos que o grande ator político comanda o "real" pelo imaginário e que, de certa forma, a arte do governo passa pela arte de "encenar". Da mesma forma, o ato de julgar passa por determinado grau de dramatização. Logo, a leitura de cartas funcionava como uma forma de proclamar a autoridade superior do rei e ao mesmo tempo tentar moldar a memória ${ }^{36}$ recentíssima do senhorio templário na região das comendas em

\footnotetext{
${ }^{34}$ Segundo a carta de 224 de junho de 1308 , os juízes teriam mandado entregar as vilas “(...) em logo de revelia, por que vos mando vista esta carta que vaadas logo aas ditas vilas e castelos e logares (...)”. Em nenhum momento, se alude a qualquer tentativa de se entrar em contato direto com os membros da Ordem no reino. 1308, junho, 29 e 30, Ega, Soure, Redinha e Pombal. I.A.N./T.T, Gav. 12, Mำ, Nº 19.

${ }^{35}$ No cerimonial judiciário tão importante quanto o que era lido era o efeito que se desejava alcançar nas sucessivas leituras. As sentenças, composições advertências, interditos eram objeto de uma exibição pública, onde o texto não era apenas lido, era "interpretado". Não era importante apenas escrever e guardar o que fora escrito nos livros de chancelaria, nos cartórios das ordens religiosas ou nas arcas dos concelhos. Era importante que estes mesmos documentos fossem consultados e relidos durante os processos judiciais. Cf., BALANDIER, Georges. Le pouvoir sur scènes. Paris: Éditions Balland, 1992.

${ }^{36}$ Efetivamente as relações entre oralidade e escrita na Idade Média eram muito complexas. O que é fundamental é que muitos por meios de poucos ditos letrados (Latim e/ou vernáculo) participavam da comunidade de leitores indiretamente, na medida em que mesmo os textos mais formais eram fabricados levando em conta o caráter oral de sua leitura e o papel dos interpretes/leitores dos textos como mediadores culturais. $\mathrm{O}$ fato das cartas em questão terem sido predominantemente lavradas no vernáculo nos fazem
} 
contenda. Na mesma carta já citada ${ }^{37}$, encontramos indícios de como a leitura de textos transladados continuou acompanhar o confisco dos senhorios templários pelo rei, no caso a leitura solene indica que a apropriação régia teria obedecido a determinada sequência de atitudes:

A qual carta lida e pubricada o dito Joham d'Amarante porteyro do nosso senhor - elrey pediu a Martinho Anes Almoxarife da Ega que lhy entregase a dita Ega em Logo de revelya pera elrey com todos seus dereytos e perteenças com mais e milhos sempre ouvera e de dereyto devia a aver. E o dito Martinho Anes Almoxarife da dita Ega fez entrega ao dito Johamd Amarante porteyro de nosso senhor elrey a dita Ega como todos seus termhos e pertenenças e dereytos (...)E logo prezente a essa ora o dito Joham d'Amarante porteyro de nosso senhor elrey recebeu a dita Ega e pro elrey e em nome Del rey em seu logo (...) fez entrega e entregou a Pero Martiinz da cryaçom de nosso senhor elrey $(\ldots)^{38}$.

A leitura era peça fundamental para a teatralização do poder na ocasião da entrega das vilas de Ega, Soure e Redinha. Mas o processo obedecia a determinada ordem lógica em sequência: a leitura pública, o pedido de entrega da vila de Ega ao Almoxarife régio Martinho Anes, a apropriação por parte do porteiro do rei, João Amarante, e a entrega a um dependente da casa real, Martinho Peres da vila de Ega. Mas alguns importantes aspectos são ocultados na narrativa da carta.

Os próprios freires templários são deixados de fora no relato do processo de tomada de posse das vilas. Em nenhum momento é citada qualquer reação de concordância ou discordância destes diante desta tomada de posse. Inclusive é explicitado que o pedido de entrega fora feito ao almoxarife, o que talvez indique que, antes do processo oficial, o poder régio já havia se apossado provisoriamente dos bens da Ordem do Templo, pelo menos desde 1307. Afirmar que essa apropriação foi feita sem violência física comparável ao processo no reino de França, nos parece razoável, contudo esvaziar

crer na sua instrumentalidade como produtora de novos significados por meio da leitura pública, que de fato ocorreu, por exemplo, nos translados apresentados nas localidades enfocadas nesse item. CARRUTHERS, Mary. The Book of memory. A Study of Memory in Medieval Culture. Cambridge: Cambridge University Press, 2008, p. 274-337.

37 A citada carta que continha os instrumentos transladados que abordamos_1308, junho, 29 e 30, Ega, Soure, Redinha e Pombal. I.A.N./T.T, Gav. 12, $\mathrm{M}^{\circ} 7, \mathrm{~N}^{\circ} 19$.

38 1308, junho, 29 e 30, Ega, Soure, Redinha e Pombal. I.A.N./T.T, Gav. 12, $\mathrm{M}^{\circ} 7, \mathrm{~N}^{\circ}$ 19. A entrega de oficial de Ega foi feita em 29 de junho de 1308. 
esse ato de suas tensões no âmbito jurídico-político — tendo em vista a clara ingerência real em assuntos eclesiásticos —é, contudo, um exagero. Esse último posicionamento só se explica diante da visão nacionalista e triunfalista mencionada na introdução desse texto.

Ao motivar a tomada das terras por revelia, de certa forma, suprimia-se o estatuto de isenta que esta Ordem do Templo detinha desde a segunda metade do século XII. Pois, ao se afirmar, implicitamente, que as Ordens militares eram assunto dos reis porque as suas terras eram oriundas de doações régias, nos questionamos até que ponto isto era bem visto por todos os eclesiásticos? Afinal, em larga medida, grande parte do patrimônio de igrejas e mosteiros teve como origem a doação régia. $\mathrm{O}$ mesmo modus operandi relatado na carta de tomada de posse de Ega é referido na apropriação dos bens da Ordem em Soure.

(...) o dito porteyro fez leer a dita carta perdante Martinho Periz alcaide e almoxary [fe] de Soury e pedyu-lhe o castelo e a vila de Soury com todos seu[s] termos e perteenças e dereytos que ela a e daquyadeante melhor deve caver que lha dese pera elrey assy como o que e contendo na dita carta. E o dito alcayde e almoxarife fez entrega e antregou o dito porteyro por elrey (...) E logo presente e essa ora dito porteyro fez entrega e entregou por elrey em nome e em logo delrey ao dito Pero Martiinz o castelo e a vila de Soury com todos seus termhos e com todas sas pertenças e com todo los dereytos que a milhor deve aver ${ }^{39}$.

O processo de entrega de Soure neste instrumento segue a mesma lógica da narrativa da entrega de Ega. Leitura pública, pedido de entrega da vila de Soure ao almoxarife e alcaide de Soure, Martinho Peres, apropriação por parte do porteiro do rei, João Amarante, e entrega a um dependente da casa real, Pero Martins. Mais uma vez se repete um padrão de narrativa que pode estar ou não efetivamente ligado ao que efetivamente aconteceu ou foi feito nas vilas em questão.

Na narrativa sobre a entrega de Soure deve ser ressaltado que a mesma foi feita por uma pessoa que ocupava duas importantes posições, a de almoxarife e de alcaide da citada vila. Em nenhum momento, é definido se este alcaide/almoxarife devia sua nomeação ao rei ou à própria Ordem. Aparentemente a nomeação deste se devia ao rei e,

\footnotetext{
${ }^{39}$ 1308, junho, 29 e 30, Ega, Soure, Redinha e Pombal. I.A.N./T.T, Gav. 12, $\mathrm{M}^{\circ}$ 7, $\mathrm{N}^{\circ}$ 19. A entrega da vila de Soure ocorreu no dia 29 de Junho de 1308.
} 
possivelmente, este alcaide/almoxarife ${ }^{40}$ já administrava o senhorio templário na vila. Mas é impossível afirmarmos isso com certeza absoluta.

O que podemos destacar com certeza é que mais uma vez os freires do Templo são suprimidos desta narrativa, tal qual ocorrera naquela que se referia à entrega de Ega. Tampouco se menciona claramente o destino das igrejas e de possíveis religiosos da Ordem ou a serviço da Ordem.

O processo de extinção da Ordem do Templo e de criação da Ordem de Cristo foi também um processo coletivo durante o qual os Juízes nomeados pelo rei, os funcionários régios, determinados setores da vilania das localidades em questão, exerceram um papel no cerimonial judiciário. A respeito das negociações que levaram à dissolução da Ordem no plano local ficamos apenas com um profundo silêncio.

Por outro lado, para justificar tal ação violenta de apropriação de bens da Igreja um discurso não claramente mencionado no plano local se tornou recorrente na relação da monarquia portuguesa com a Santa Sé no contexto de 1311 a 1319. De certa forma, a própria documentação do Concílio de Vienne também trazia pistas para os poderes soberanos peninsulares do conjunto de argumentações que seriam mais eficazes diante da Santa Sé.

\section{Portugal e a luta contra os muçulmanos. $O$ conjunto de argumentos preponderantes no contexto pós-Concílio de Vienne (1311-1312)}

O Concílio de Vienne representa um marco no que tange à história das relações entre monarquias e poder pontifício. Um dos temas mais debatidos foi a problemática do que se fazer para preservar os bens da Ordem do Templo e qual o destino que se deveria dar aos antigos ocupantes da Ordem. As soluções variaram conforme as relações estabelecidas pelos diversos reinos com a coroa francesa ${ }^{41}$.

A despeito da iniciativa de dissolução da Ordem do Templo ter partido principalmente do rei de França e de parte do episcopado do referido reino, é interessante

\footnotetext{
${ }^{40}$ Os alcaides e almoxarifes que fazem a entrega não são citados como membros ligados a Ordem do Templo. Caso contrário isto por si só descaracterizaria à revelia.

${ }^{41}$ Não nos propomos nesse texto aprofundar todo o complexo processo de dissolução da Ordem do Templo em França, só mencionaremos este processo quando julgarmos conveniente estabelecer comparações com o processo na Península Ibérica. Mas concordamos com Demurger quando afirma que um dos principais fatores que levaram a extinção Templo deve ser buscado no projeto de Felipe IV em relação a liderança em uma nova cruzada e por conseguinte, a intenção de estabelecer uma certa hegemonia na Cristandade Ocidental. DEMURGER, Alain. Vie et Mort de L'Ordre du Temple ( 1118 - 1314 ). Paris: Éditions du Seuil, 1989, p 277-279.
} 
que nos ocupemos momentaneamente de alguns dos principais argumentos pontifícios contidos na ata do Concílio de Vienne para a dissolução da Ordem. Para tal propósito, será particularmente importante analisar algumas das bulas publicadas nas atas.

O citado concílio foi convocado por Clemente V (papa de 1305-1314) ${ }^{42}$, pela bula Regnans in coelis, escrita em Poitiers em 12 de agosto de 1308. Nesta época, as pressões sobre o poder pontifício eram imensas, sobretudo as exercidas por Felipe, o Belo, com o objetivo de alcançar a condenação do papa Bonifácio VIII (papa de 1294-1303) e a condenação da Ordem do Templo.

O sínodo foi convocado para se iniciar em Vienne, em 1310, mas só foi possível iniciá-lo efetivamente mais tarde. Tanto o poder régio de França quanto o poder pontifício buscavam assegurar apoios necessários para a discussão, neste encontro de assuntos que haviam tomado proporções imensas no contexto político da época, tais como as da suposta heresia de Bonifácio VIII e as graves acusações apresentadas contra a Ordem do Templo.

Somava-se a estas duas questões o clima de profunda frustração proporcionado pela queda de Acre em 1291, ao menos em certos setores da cúria e da realeza francesa. Um dos objetivos do concílio era viabilizar a organização de uma nova cruzada.

O concílio apenas iniciou-se em 16 de outubro de 1311 em presença de 20 cardeais, 4 patriarcas e por volta de 100 arcebispos e mais alguns abades e priores. No discurso inicial de Clemente V, três questões se apresentaram como fundamentais, o processo dos templários, a questão da Terra Santa e a Reforma da Igreja. A questão de

\footnotetext{
${ }^{42}$ MENACHE, Sophia. Clement V. Cambridge Studies in Medieval Life and Thought. Cambridge:
} Cambridge University Press, 1998, p. 112-120. 
Bonifácio VIII permanecia como pano de fundo, como algo que poderia ser utilizado para comprometer de forma ainda mais profunda o poder hierocrático ${ }^{43} \mathrm{do} \mathrm{papado}^{44}$.

No Concílio de Vienne, cuja primeira sessão abriu a 16 de Outubro de 1311, estiveram presentes, em representação do episcopado de Portugal, D. Martinho, arcebispo de Braga, D. Fr. Estêvão, bispo do Porto e D. Rodrigo, bispo de Lamego. Para além destes clérigos, D. Dinis enviou alguns outros delegados seus ${ }^{45}$. Estavam presentes ainda os enviados das Coroas de Castela, Aragão e Maiorca, defendendo um estatuto especial para o patrimônio templário nos respectivos reinos. Em 22 de março de 1312, Clemente V lavraria o decreto de abolição da Ordem do Templo ${ }^{46}$.

Acontece que o desempenho das ordens militares hierosolimitanas, no que se refere à queda da Terra Santa, era visto com desconfiança por muitos, frequentemente era oficiosamente imputada a estas a principal responsabilidade pela derrota cristã. Para admitir que fosse possível a queda da Cidade Santa em mãos infiéis, determinada explicação foi mais facilmente aceita: a queda fora um castigo pelo pecado e venalidade dos cristãos, em particular os das próprias ordens militares, na medida em que a situação dos hospitalários não era tão melhor que a do Templo. $\mathrm{O}$ fato de a primeira dessas ordens

\footnotetext{
${ }^{43}$ Utilizamos a expressão hierocracía levando em conta relações de poder que se remetem a um contexto institucional da história da Igreja no qual o papado desde o século XI buscou assumir um papel preponderante no âmbito da Cristandade, buscando subordinar à sua liderança os demais poderes dentro e fora da Igreja. O papado tendeu a aceitar a dualidade de poderes temporal e espiritual, contanto que este último poder tivesse necessariamente superioridade sobre a esfera temporal. Por outro lado, em nome da dualidade imperadores e reis tentaram a recusar essa lógica de subordinação de uma esfera a outra, reforçando que detinham autonomia no poder temporal, que havia sido igualmente estabelecido pode Deus. Esse debate em linhas gerais atravessou os séculos finais da Idade Média sendo parcialmente estabilizado com ascensão do Estado confessional Moderno. BURNS, J.H. Histoire de la pensée politique médiévale. 350-1450. Paris: Press Universitaires de France, 1995, p. 348; Cf. GOMES, Francisco Jose da Silva. A Igreja e o poder: representaçõees e discursos . In: RIBEIRO, Maria Eurydice de Barros (org.). A vida na idade média. Brasília: Editora Universidade de Brasília, 1997, p. 34-60.

${ }^{44} \mathrm{Cf}$. Texto das atas do concílio de Vienne In: Le magister de L'église Les conciles Aecuméniques. Les Decréts. Tome II_1 Nicée I à Latran V. (Text Originel établi per, ALbergno , G ; DOSSETI; JOANSON, P._P). Paris: CERF , 1994, p.703-709. É importante explicitar que a edição crítica que utilizamos é bilíngue (latim/francês). No entanto os trechos efetivamente citados neste trabalho foram traduzidos diretamente do original. Durante a leitura nem sempre concordávamos com as opções do tradutor. Utilizaremos daqui por diante Vienne, seguido da página da versão publicada que utilizamos.

${ }^{45}$ No período de 1310 a 1319 , segundo Porro teriam sido enviados à cúria: 1310, frei Estevão Bispo do Porto; os referidos Bispo do Porto, de Coimbra e o Arcebispo de Braga para o Concílio de Vienne 13111312; em 1313 o frei Estevão bispo de Lisboa para discutir também a questão dos bens dos Templários; 1314-1316 João Vicente e Lourenço Eanes, para discutir a questão dos bens do templo e outros assuntos; 1317-1318, Manuel Peçanha e Vicente Annes, para discutir a separação da Ordem de Santiago de Leão; e em 1318-1319 João Lourenço e Pero Pires, para discutir a criação da nova Ordem de cristo. PORRO, Clive. Reassessing the Dissolution of the Templars ...Op.cit. p. 177.

${ }^{46}$ Ibidem. Cf. GOMES, Saúl Antônio. Revista de História da Sociedade e da Cultura, Vol. 11, 2011, p. $75-116$.
} 
possuir sua sede em Chipre, desde 1309-1310, por outro lado, deixava o convento central que regia aos hospitalários a salvo de uma ação tão intrusiva, como no caso do Templo que, por sua vez, tinha seu centro de poder no âmbito do reino de França ${ }^{47}$.

Uma perspectiva crítica é registrada nas atas do Concílio de Vienne em que se explicitava de forma alegórica a opinião oficial do papado (que possivelmente também era de tantos outros) no que se refere à perda dos territórios na Terra Santa pela Cristandade Latina, após a queda de Acre em 1291, tal como na bula Vox in excelso, datada de 22 de março de $1312^{48}$ :

Uma lamentação se faz ouvir do alto, choro e aflição, pois é chegado o tempo, e o tempo veio, no qual o senhor se lastima pelo seu profeta: $<$ esta casa se tornou um objeto de furor e indignação. Ela será subtraída de minhas mãos por causa da malícia de seus filhos, por que eles provocam a minha cólera ao me mostrar suas costas e não o seu rosto, colocaram ídolos em suas residências, onde meu nome não é invocado, para desta forma profanar. Eles construíram um altar para Baal para consagrar seus filhos aos ídolos e demônios $>{ }^{49}$.

A utilização alegórica deste trecho do profeta Jeremias (Jr 32, 31-35) reflete de forma erudita a sensação de desconforto que se sentia em determinados meios. A expressão malitiam filiorum suorum sugeria que a ordem hierárquica do mundo, que culminaria em Deus, havia sido quebrada e cabia à Igreja tentar restabelecê-la.

O grande papel ocupado pelas ordens militares na defesa da Terra Santa, no século XIII, era de conhecimento de muitos, mas conforme as derrotas se sucederam, na segunda metade do século XIII, foi se formando um clima crescente de desconfiança com relação a essas instituições.

\footnotetext{
${ }^{47}$ BURGETORF, Jochen; CRAWFORD, Paul F.; NICHOLSON, L. J. (org.). Op.cit., p. 11-20.

${ }^{48}$ A bula foi lida em assembleia solene no concilio em 3 de abril de 1312 diante do rei de França. Mas antes de leitura foi anunciado que qualquer um que ousasse tomar a palavra seria excomungado. Buscava-se evitar que a composição informal entre o papado e a monarquia francesa para a dissolução da Ordem fosse questionada durante o concílio. Cf. THÈRY, Julien. Procès des templiers In N. BÉRIOU, Ph. JOSSERAND (dir). Dictionnaire européen des ordres religieux militaires. Paris : Fayard, 2009. p. 743-750.

49 "Vox in excelso audita est lamentationis, fletus e luctum:<in furorem et indigantionem mihi facta domus haec. Auferetur de cosnpectu meo propter malitiam filiorum suorum, quia me ad iracundiam provocabant, vertentes ad me terga et non facies, ponentes idola sua in domo, in qua invocatum est nomen meum, ut pollueruntipsam. Aedificaverunt Baal, ut initiarent et consecrarent filios suos idolis atque daeminis $>$." Vienne, p. 698-699.
} 
Desde as décadas de 1260/1270, os reinos cruzados foram se reduzindo a uma franja costeira, defendida quase que exclusivamente pelas fortalezas das ordens hierosolimitanas (e pelos recursos das mesmas), constantemente acossadas pelos mamelucos, a situação aos poucos se tornou insustentável: o abandono de territórios e fortalezas tornou-se quase inevitável. Esta prática contribuiu para aumentar a desconfiança entre os ocidentais recém-chegados e mesmo no próprio Ocidente em relação às ordens militares hierosolimitanas.

Os reinos cruzados pagaram tributos e resgates de prisioneiros e, quando podiam, sustentavam modestos ataques, incapazes de possibilitar qualquer esforço de conquista de territórios. Este conjunto de dificuldades era vista por muitos como "má-vontade", perspectiva logo transformada em uma atitude ofensiva, sobretudo por parte de setores do clero secular, que viam nas derrotas sucessivas das ordens militares o sinal de pactos secretos, conversões silenciosas ou mesmo lançavam abertamente sobre estas a suspeita de heresia ${ }^{50}$.

Dois conjuntos de críticas direcionadas às ordens militares hierosolimitanas eram recorrentes. No caso do clero secular, ora se criticava a suposta avareza, altivez e a agressiva rivalidade entre as ordens hierosolimitanas; ora se criticava o suposto desperdício dos bens que deveriam ser utilizados para a manutenção da guerra contra o islã. As ordens militares incomodavam ao clero secular por não pagarem dízimos e anatas tal qual faziam outras instituições religiosas isentas; e, ao mesmo tempo, estas ordens desfrutavam de um poder extremamente independente do poder de jurisdição episcopal. Em 1292, um grupo de bispos chegou a se reunir em Reims para discutir a possibilidade de confiscação dos bens dessas ordens ${ }^{51}$.

Logo, mesmo as vozes que se levantaram em defesa das ordens propunham que as ordens do Hospital e dos Templários fossem integradas em uma única instituição como forma de potencializar ações de defesa ou, após a queda de Acre, possibilitar recuperação da Terra Santa. Os críticos menos "inflamados" destas ordens reconheciam, portanto, a experiência e a disciplina militar destes monges-guerreiros ${ }^{52}$. Estas duas últimas assertivas é que sustentavam os posicionamentos moderados em relação às ordens e que inspiravam novas ideias de reformas destas instituições monástico-militares, que

\footnotetext{
${ }^{50}$ DEMURGER, Alain, Op. Cit, p.276.

51 Ibidem.

${ }^{52}$ Ibidem, p. 277.
} 
deveriam até, segundo alguns, ser lideradas pelo poder leigo. A ideia de fusão estava profundamente interligada às ideias de moralização e de eficácia que conduziriam, por conseguinte, à recuperação da Terra $\operatorname{Santa}^{53}$. Dois aspectos que ocuparam um importante lugar desde pelo menos o Concílio de Lyon de 1274.

Mas no Concílio de Lyon, no que se refere à possibilidade de fusão das ordens, o poder pontifício recebeu uma clara negativa do rei de Aragão. Postura que de certa forma prenunciava a que seria futuramente tomada por ocasião do processo de extinção oficial da Ordem do Templo, ocasião em que o rei de Aragão se negou a devolver os bens do Templo para os hospitalários. Já em 1274, se aventava a possibilidade de se fundar uma ordem única, questão que ficaria mais explícita no contexto do Concílio de Vienne de $1311-1312^{54}$.

Após a queda de Acre, em 1291, a situação política das ordens se complicou, alguns questionavam a utilidade de sua existência, outros, ainda, o fato de que a despeito da suposta grande riqueza destas, elas não implementaram uma política mais coerente de retomada da Terra Santa.

Em 1305, o papa Clemente V pediu aos mestres do Templo e do Hospital para redigirem conselhos para a organização de uma cruzada e sobre a possibilidade de fusão das ordens ${ }^{55}$. Ambos os mestres redigiram os textos: Jacques de Molay, um texto mais geral; Villaret de Foulques, mestre do Hospital, um texto mais preciso, que propunha um verdadeiro plano de ação que apresentava, como data inicial das operações, os anos de $1307-1310^{56}$.

Segundo Alain Dermuger, por ocasião da elaboração desses relatórios, talvez os mestres já suspeitassem de que algo estivesse para acontecer, sobretudo por causa das posturas assumidas por Felipe, o Belo, e seu conselheiro Nogaret em relação a Bonifácio VIII $^{57}$, se foi possível um ataque a uma instituição tão sólida quanto o papado, quanto mais a instituições que sofriam pesadas críticas tal como as ordens militares hierosolimitanas.

\footnotetext{
${ }^{53}$ Vienne, p. 637-695.

${ }^{54}$ DERMUGER, Op.cit., p. 279.

${ }^{55}$ Ibidem.

${ }^{56}$ Ibidem.

57 Posturas que são bastante comentadas pela literatura corrente sobre o assunto e desta forma nos desobrigamos de retomá-las nessa ocasião.
} 
Em junho de 1306, Clemente V convocou os mestres da ordem do Templo e do Hospital que já tinham em mãos os relatórios anteriormente pedidos. Em fins de 1306 ou início de 1307, Jacques de Molay chegou à França acompanhado do praeceptor de Chipre, Raimbaud de Cahon, o mestre do Hospital chegou apenas em agosto de 1307, pois estava ocupado com as questões relativas à conquista da ilha de Rodes ${ }^{58}$.

Foi justamente a partir de 1305 que a relação entre a Ordem do Templo e a monarquia francesa se complicou. Mas é possível encontrar antecedentes deste conflito na postura assumida pelos Templários no incidente de Anagni, oferecendo seu apoio militar ao próprio papa por ocasião da invasão da vila pelos enviados do rei de França, a despeito de os Templários do reino de França terem se colocado ao lado de Felipe IV nas disputas com a Santa Sé.

Um ambiente de crítica, de desconfiança e de frustração forneceram um terreno de sustentação para as inúmeras acusações lançadas contra os Templários. E o peso destas acusações refletiu-se ainda nas sessões do Concílio de Vienne. A queda da Terra Santa tinha a origem na conduta dos freires, que com atitudes censuráveis abriram a possibilidade para a derrota cristã. Mais uma vez encontramos, na linguagem alegórica da documentação, sobre o concílio - feita em sua forma final à posterirori deste - a fundamentação de nossa perspectiva, pois foi afirmado que:

O senhor não escolheu um povo em função do lugar, mas o lugar em função do povo. E por que neste mesmo lugar onde se encontra o templo partilhou as faltas do povo, como anunciou o senhor Salomão que reconstruísse o templo com sabedoria:<<se vossos filhos se afastarem de mim e não mais me seguirem e não mais me oferecerem culto, mas se afastarem e oferecerem culto aos deuses estrangeiros e os adorarem, os retirarei de minha face e os expulsarei da terra que lhes dei, e os retirarei de minha face o templo que santifiquei com meu nome, e ele se tornará um provérbio, alvo de maledicência para todos os povos $>>$. Todos os transeuntes ficarão estupefatos e reduzidos ao silêncio, e eles dirão: <<Por que o senhor fez a este templo e a esta morada?>> E eles responderão: <<porque eles se afastaram de seu Deus, que os recebeu e os restituiu, e seguiram a Baal e aos outros deuses estrangeiros, onde eles

${ }^{58}$ Ibidem. 
adoram a e ofereceram culto. Por esta razão o seu senhor os irá atingir com um grande mal.>>. ${ }^{59}$

No discurso da bula Vox in excelso, de março, de 1312, de Clemente V, a Ordem do Templo estava comprometida implicitamente pelo comportamento de alguns de seus membros. As relações simbólicas intrínsecas da Ordem com o local do antigo Templo de Salomão, o peso lançado em textos bíblicos que se referiam à queda do templo e da cidade (1 Reis 9, 6-9), a tudo isso se somava a profunda antipatia por parte de amplos setores do clero secular em relação à Ordem do Templo. A despeito disso, religiosos e clérigos seculares presentes no concílio recusavam condenar a Ordem como instituição ${ }^{60}$. Afinal, estava implícito que era preciso reafirmar a autonomia e as liberdades da Igreja diante da investida do poder temporal de reis e príncipes.

Esta Ordem poderia até não ter sido considerada pela maioria dos seus contemporâneos culpada das acusações de sodomia e heresia lançada pelo rei de França, mas provavelmente aos olhos do papado e de alguns poderosos potentados eclesiásticos a Ordem era uma das grandes culpadas pela queda da Cidade Santa. E efetivamente seus membros teriam em parte incorrido em práticas condenáveis que não eram necessariamente as que foram afirmadas no processo de dissolução em França por parte dos agentes de Felipe, o Belo.

Em 20 de março de 1312, Felipe IV foi pessoalmente a Vienne, pressionando, ao máximo, com sua presença (e de suas tropas), os membros do concílio e, em 22 de março, foi emitida a bula Vox in Excelso. Mas uma das questões mais complexas que esta situação gerava era como transformar a profunda ingerência leiga em um assunto

\footnotetext{
59 "Non enim propter locum gentem, sed propter gentem locum elegit DominusIdeo et ipse templi particeps factus est populi malorum, ipso Domino ad Salomonem aedificantem sibi templum, qui impletus est quasi flumine sapientia, apertissime praedicante: $<<$ Si aversione aversi fueritis filii uestri, non sequentes et colentes me sed abeuntes et colentes deos alienos et adorantes ipsos, proiciam eos a facie expellam quam dedi eis, et templum quod santificavi nomine meo a facie mea proiciam, et erit prouerbiam et in fabulam et populis in exemplum. Omnes transeuntes videntes stupebunt et sibilabunt, et populis in exemplum, et dicent: $<<$ quare sic fecit Dominus templo et domui huic? Et respondebunt: $<<$ quia recesserunt a domino deo suo, qui emit et redemit eos, e secuti Baal et deos alienos et adorauerunt eos et coluerunt. Idcirco induxit Dominus super ipsos hoc malum grande >>”. Vienne, p. 669. Negritos são nossos.

${ }^{60}$ Segundo as atas do concilio a maioria dos cardeais e cerca de $4 / 5$ dos presentes no concilio após leitura da versão do processo apresentada pelo papado, ao serem consultados de forma secreta foram contra a condenação da Ordem. No caso se tratava da maioria dos que foram eleitos da massa dos presentes enquanto comissão encarregada de discutir o processo. Na eleição feita pelos homens de Igreja, com pressão pontifícia, lançava-se uma espécie de sutil contra-ataque às atitudes de Felipe, o Belo em especial. Todavia, foram selecionados pelo papa aqueles que seriam mais maleáveis ao acordo informal como a monarquia francesa, ou seja a maioria nessa comissão foi manipulada. Vienne, p. 708.
} 
eclesiástico (o suposto comportamento inadequado dos membros da Ordem) em algo aceitável para concepção hierocrática de poder. Ou o poder secular recuava, o que de fato não aconteceu, ou na prática a concepção hierocrática tinha de ser revista e adaptada.

Era, portanto, preciso estabelecer uma nova relação de poder, que passava pelo compromisso informal entre o poder pontifício e o poder régio francês. $\mathrm{O}$ modelo de Cristandade segundo os moldes lançados pela reforma gregoriana, que sequer chegou a ser plenamente implantado em qualquer localidade, sofreu a um golpe decisivo. O modelo hierocrático de poder teve de ser adaptado ao contexto de profundo fortalecimento das monarquias territoriais. Isto implicava a remodelação concreta das relações entre os poderes.

O que estava em questão durante o concílio era nada mais, nada menos, que a legitimidade das atitudes de Felipe, o Belo, e quais os limites efetivos da autoridade apostólica. Na bula Ad perpetuam, de 22 de março de 1312, Clemente V buscava explicitar quais eram as extensões de seus poderes na questão dos templários, o tom e o conteúdo de seu discurso neste documento demonstra ser bem mais modesto que a bula Una Sancta de Bonifácio VIII, pois afirma que:

Pertence à vigilância previdente do vigário de Cristo, que preside o cimo da dignidade apostólica, de avaliar o encadeamento das circunstâncias, de examinar as causas das questões que surgem e de levar em conta a qualidade das pessoas, de forma que, em acordo a cada coisa dê a atenção merecida (...) ele arranca do campo do senhor os espinhos dos vícios, que ele faça crescer as virtudes, que arranque os espinhos dos prevaricadores, que ele plante mais do que destrua $(\ldots)^{61}$

No que tange ao governo moral, ao poder de Ordem, a supressão ou criação de novos estatutos, o poder do papado é amplo, apesar de precisar agir in consilio, mesmo que a consulta a este em alguns momentos tenha sido algo quase que estritamente formal. A normatização do comportamento de monges e clérigos, a condução espiritual dos leigos, tudo isso deveria fazer parte das atribuições pontifícias, mas a supressão da Ordem do Templo só ocorreu por uma grande pressão do poder leigo do rei de França. Fica-se

\footnotetext{
61 "Ad providam Christi vicarii praesidentis in specula apostolicae dignitatis circunspectionem pertinet, vices pesare temporum, emergtentium negotiorum causas discutere ac personarum attendere qualitates, ut ad singula debitum dirigens necessariae considerationis (....), de agro Domini sic vitiorum tribulo seruat ut virtutes amplificet, sic praevaricantium spinas tollat ut evellendo plus plantet quam destruat (...)". Vienne, p. 712.
} 
com a impressão na leitura dessa bula de que este concílio teve como uma das principais preocupações a manutenção quase que estritamente formal da liderança do papado no que se refere à Cristandade. Buscava-se adaptar e reforçar no mundo dos conceitos o que se percebia como fragilidade do poder espiritual diante da crescente autonomização do poder temporal.

Para preservar as aparências de um poder que se queria com grande ascendência sobre os príncipes seculares, era necessário ceder em algumas questões, ainda era de fresca memória o quanto o rei de França foi incisivo no caso de Bonifácio VIII. Era necessário dividir com os príncipes seculares os cuidados com os rumos da Igreja. Era necessário tratar o poder de fato dos reis sobre as igrejas locais em seus reinos como se fosse algo implicitamente ou explicitamente concedido pelo papado. A complexa crise política que levou a dissolução da Ordem do Templo punha em relevo o quanto a concepção hierocrática de poder já não dava conta de uma realidade política tão complexa como a do início do século XIV.

Ainda na bula Vox in excelso, de 22 de março de 1312, buscaram-se apresentar outros argumentos para a dissolução da Ordem que, a nosso ver, estão intimamente ligados à necessidade de preservar a Igreja enquanto modelo de sociedade perfeita ${ }^{62}$ diante da profunda ingerência leiga, ao menos no caso dos templários, pois foi em razão:

(....) do enlameamento do mestre, dos freis e de outras personas desta Ordem, residentes em todas as regiões do mundo, por causa das obscenidades, das depravações, das manchas, das faltas diversas e variadas - que são tão indizíveis quanto desgraçadamente inauditas(....). Nos desde agora suprimimos, não sem tristeza nem dor, a Ordem da Milícia do Templo de Jerusalém, assim como o estado dessa Ordem, seu hábito seu nome, por uma decisão irrefragável com valor perpétuo, não por sentença definitiva , pois, neste assunto, mas por meio de provisão e ordem apostólica $(\ldots . .)^{63}$.

\footnotetext{
${ }^{62}$ CF. GOMES, Op.cit. A Igreja e o poder...

63 "Dudum siquidem ordinem doums Militiae Templi Ierosolimitani propter magistrum et fratres ceterasque personas dicti ordinis in quibuslibet mundo partibus consistentes variis et diversis non tam nefandis quam infandis, proh dolor, errorum et scelerum obscenitatibus, pravitatibus, maculis et labe respersos, quae tristem et spurcidam eourum memeoriam praesentibus eiusque ordinis statum, habitum atque nomennon sine cordis amaritudine et dolore, sacro approbante concilio, non per modum diffinitivae setentiae, cum eam super hoc secundum inquiper modum diffinitivae sententiae (...) sed per viam provisionis seu ordinationis apostolicae, irrefragabili et perpetuo valitura substulimus sanctione (...)”. Vienne, p. 712.
} 
A questão é que a Ordem não foi condenada cabalmente, foi considerada suspeita devido ao comportamento de alguns dos seus principais membros, que supostamente confessaram suas falhas e desvios (mediante medo, tortura ou conveniência). Mas os procedimentos utilizados não foram considerados canônicos ${ }^{64}$. É interessante observarmos que as confissões são reputadas como espontâneas ${ }^{65}$, o que nos parece ser o eufemismo necessário para tornar justificável a intervenção pontifícia e ao mesmo tempo permitir a este último poder tentar retomar a direção formal dos acontecimentos.

Segundo o poder pontifício, os templários foram condenados por terem alcançado uma má reputação e esta suspeita tornava a ordem abominável e detestável à santa Igreja de Deus e aos seus prelados, da mesma forma que aos reis, aos príncipes aos outros católicos $^{66}$. Em outras palavras, a Ordem do Templo comprometia o corpo da Igreja e a tornava a Ordem inútil para cuidar das questões da Terra Santa ${ }^{67}$.

Nesse contexto de dissolução da Ordem a liderança régia na continuidade do projeto de Reconquista, que em certas situações ao longo os séculos XII e XIII assumiu caraterísticas de cruzada, oferecia a autoridade moral que os reis Ibéricos precisavam para firmar pé em suas negociações junto ao poder pontifício. Pelo menos, é possível perceber isso de forma retrospectiva.

O período que vai de 1308 a 1319 é caracterizado pelo esforço de reis e papado em normatizar e minorar os efeitos do ataque e dissolução da Ordem do Templo e de direcionamento de bens da Ordem. Em primeiro de fevereiro de 1313, o papa pediu aos reis Ibéricos que apresentassem suas posições, pois era importante especificar qual o destino dos bens e igrejas da Ordem do Templo na Península Ibérica. Por volta do período do Concílio de Vienne, o rei Castela Fernando IV estava morto e seu filho Afonso XI era menor. O rei Jaime II de Aragão fora de longe mais ativo dentre os reis ibéricos na questão dos bens do Templo ${ }^{68}$.

\footnotetext{
64 "Verum licet ex processibus habitis contra ordinem memorantum ipse ut haereticalis per diffinitivam sententiam sententiam canonice condenari non possit(...). Ibidem, p.708

65 “(...) per eorum confessiones spontaneas de praedicitis haeresibus, erroribus et sceleribus (...)”. Ibidem.

66 "(...) est plurimus diffamatus, et quia quase infinitiae personae illius ordinis, inter quas sunt generalis magister, visitator Franciae et maiores praecpetores ipsius, per eorum confessiones spontaneas de de praedicitis haeresibus, erroribus et sceleribus sunt convictae, quia infamia et suspicio praelibatae dictum ordinem reddunt ecclesiae sanctae Dei et praelatis eiusdem ac regibus aliisque princibus et caeteris catholicis nimis abominabilem et exosum(...)”. Ibidem.

67 "(...) quod amodo bona non reperitur persona, quae dictum ordinem vellet intrare, propter quae ipsi ordo ecclesiae Dei ac prosecutioni negotii terrae sanctae (...)”. Ibidem.

${ }^{68}$ DEMURGER, Alain. Op.cit., p. 227.
} 
O rei de Aragão havia anteriormente dado aos seus embaixadores junto ao Concílio de Vienne instruções bem precisas em que delimitava que os bens dos templários em seu reino não deveriam ser entregues aos Hospitalários. Na perspectiva deste rei, esta entrega poderia fazer crescer o orgulho dos hospitalários, pois estes não serviam nem ao "senhor" nem ao papa condignamente ${ }^{69}$. O rei de Aragão acreditava profundamente na possibilidade da formação de uma nova ordem sob o pretexto dar continuidade à Reconquista.

As discussões do rei de Aragão junto ao poder pontifício foram retomadas entre 14 de fevereiro e primeiro de abril de 1313, mas nesta última data as negociações voltaram praticamente à "estaca zero". Entre a morte de Clemente V e a eleição de João XXII as negociações permaneceram praticamente paralisadas ${ }^{70}$. Em 1314, Clemente V chega a declarar que os dízimos a serem levantados deveriam ser utilizados para a recuperação da Terra Santa ou em qualquer lugar na luta contra os inimigos da fé cristã $\tilde{7}^{11}$.

Em 1316, Jaime II propôs que o castelo de Montesa, situado na parte setentrional do reino de Valência se tornasse o "quartel-general" de uma nova Ordem filiada à Calatrava. João XXII aceitou bem a criação desta nova Ordem e estabeleceu que o mestre de Calatrava teria direito de visitação sobre a mesma. Nos assuntos religiosos o mestre de Calatrava seria assistido pelo abade cisterciense de Santa Creus (uma abadia catalã). Em 10 de junho de 1317, a bula ad fructus uberes e a bula Pia matris ecclesie consolidaram o processo de criação da Ordem de Montesa ${ }^{72}$.

Em Portugal, a integração dos bens Templários em uma nova Ordem Militar foi alcançada por meio da bula Desiderantes ea ex quibus, de 14 de março de 1319. Nessa bula, é apresentada a versão oficial pontifícia para a extinção da Ordem do Templo e o empenho dos Reis de Castela, Aragão, Portugal em solicitar que os bens da citada Ordem não passassem para a Ordem do $\operatorname{Hospital}^{73}$. Utilizaremos aqui a versão transladada para o vernáculo pelo seu potencial à época de alcançar um conjunto maior de pessoas, pois inclusive boa parte dos freires-cavaleiros da Ordem que se constituía não devia estar tão bem familiarizada com o latim.

\footnotetext{
${ }^{69}$ Ibidem.

${ }^{70}$ Ibidem.

${ }^{71}$ MENACHE, Op.cit., p. 116.

${ }^{72}$ DEMURGER, Alain. Op.cit., p. 227.

${ }^{73}$ Monumenta Henricina, v. 1. Coimbra, Comissão Executiva das comemorações do V centenário da Morte do Infante D. Henrique, 1960, p. 111.
} 
A bula apresenta também o que era considerado pelo papado como um dos mais importantes argumentos apresentados pelos procuradores do rei D. Dinis, Pero Perez, cônego de Coimbra, e João Lourenço de Montsserá (cavaleiro) em 1318/19, que teriam sugerido ao poder pontifício que:

(...) aquela lixosa naçon dos dictos mouros enmiga sem piedade do nome de christo, que he fronteira do dicto rreyno do algarve, como parte per seus termhos com esse rreyno, como dito he, atormentou, per alguuas uezes, o dicto rreyno e os fiees que em elmorauam com muytas tribulações, em desonra do rrey do ceo e os meteu em desuayrados perigoos e armou per muytas uezes e trabalha armar, em destroymento deles, de que nos deuemos muyto doer. ${ }^{74}$

Efetivamente esta perspectiva era também ideológica e encontrava grande ressonância dentro e fora da Península. Na Península Ibérica, a nova frente de combate contra o islã era nas fronteiras de Castela com o reino de Granada ou na indeterminada fronteira marítima em que a pirataria cristã e muçulmana tinha um papel fundamental ${ }^{75}$. As principais ameaças muçulmanas para o reino de Portugal eram as investidas marítimas do reino mouro de Granada e os ataques marítimos oriundos do norte de África.

\footnotetext{
${ }^{74}$ Ibidem, p.113.

${ }^{75}$ Deve-se valorizar o fato do reino de Portugal, desde finais dos duzentos ter se consolidado como ponto obrigatório de passagem de navios que trafegavam entre o mediterrâneo e o Atlântico Norte, o que indiretamente ofereceria a Portugal uma posição menos periférica dentro do panorama econômico e político da época, tendência que se intensifica no século XV. Em outras palavras, o reino de Portugal se posicionava como um importante ponto de apoio do comércio marítimo em fins do século XIII. Ao mesmo tempo, a partir do reinado de D. Dinis ocorreu a modernização das embarcações, das técnicas marítimas e ao mesmo tempo uma melhor organização da defesa das costas portuguesas, sobretudo nas algarvias. Tais ações foram contemporâneas à criação da nova Ordem. Uma forte corrente de comércio era dirigida do reino de Granada, passando por Portugal, Inglaterra, Flandres e também entre o citado reino granadino e o sultanato merinida em África. Nesta corrente estava integrada também uma prática corsária cotidiana. A realização de fossados do mar, por parte das forças cristãs é algo que se detecta desde o período anterior ao termino da reconquista portuguesa. Mas frequentemente a embarcação era vista apenas como um meio de transportar às tropas até a região de ataque. Incursões de defesa e de ataque às costas do reino de Granada ou mesmo do norte da África se intensificaram no decorrer do século XIV. Pérez, Maria Dolores López. Uma Frontera no determinada: las atividades corsárias catalanas y granadinas em el mediterrâneo occidental (siglo XIV). Revista da Faculdade de Letras. tomo. II. Vol. XV-2, 1998, p. 868-873. MARQUES, A. H. de Oliveira (dir.). Nova História da expansão portuguesa. A expansão quatrocentista. Vol. II. Lisboa: Editorial Estampa, 1998, p. 11-32 ; FONSECA, Luís Adão da. Portugal e o Mediterrâneo, entre Castela e Marrocos : a formação da fronteira marítima nos séculos XIV-XV e a noção de espaço político descontínuo. Porto: CEPESE-Centro de Estudos da População, Economia e Sociedade, 2009, p. 48.
} 
A doação de Castro-Marim obedecia também a uma lógica de defesa das fronteiras contra o reino de Castela. A doação do castelo e da vila citada configuraria ainda o propósito de constituir no sudeste algarvio, uma praça forte para dissuadir quaisquer pretensões da Ordem de Santiago da Espada nesta região, já que esta última Ordem era particularmente ligada aos reis de Castela.

A Ordem de Cristo pela referida bula era oficialmente integrada a determinado conjunto de ações do poder régio em Portugal que passava pelo estabelecimento de fronteiras estáveis, o reforço do aparelho administrativo régio, do aparelho judicial, da organização militar (sobretudo das fronteiras) e andava a par com um esforço de manter o prestígio do reino junto a outros monarcas Ibéricos e junto ao papado.

A criação da Ordem de Cristo estava ligada, portanto, também ao jogo de forças relativamente subjetivo proporcionado pela tutela sobre esta Ordem. A ideia de cruzada era algo que pesava substancialmente na perspectiva da época e não era apenas uma formalidade diplomática, o que fica explícito nos motivos apresentados pelos procuradores segundo a narrativa do papado na bula oficial de 1319. Segundo o papa:

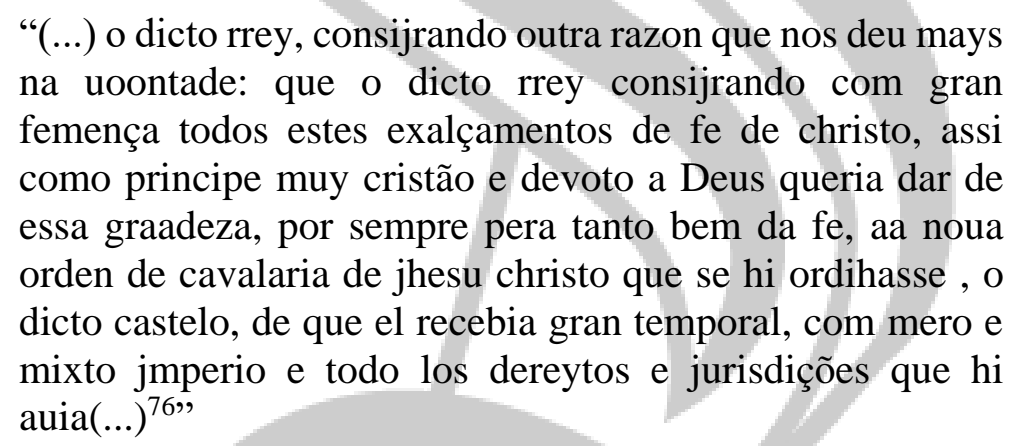

Ao conceder ao rei de Portugal ampla influência sobre uma Ordem Militar e religiosa, não podemos deixar de perceber que algo estava mudando na compreensão que o próprio papado tinha do papel dos governantes cristãos. Pois, se a desonra ao "rrey do ceo"77 era propiciada pelos ataques muçulmanos, caberia indubitavelmente ao rei, com sua potestas $^{78}$, a tarefa de conduzir esta empreitada vista como cruzadística pelo

\footnotetext{
${ }^{76}$ Monumenta Henricina, v. 1. Coimbra, Comissão Executiva das comemorações do V centenário da Morte do Infante D. Henrique, 1960, p.112.

${ }^{77}$ Ibidem, p. 113.

${ }^{78} \mathrm{O}$ papel do rei de liderança nas empreitadas militares é algo que remonta aos primórdios de formação do reino e propicio ao poder régio uma posição de particular ascendência sobre as instituições eclesiásticas, sobretudo nas regiões que iam sendo reconquistadas. Neste sentido, parece extrapolar parcialmente a
} 
papado $^{79}$, ou seja, em certa medida o papado abria mão da liderança na luta contra os infiéis, liderança que do ponto de vista formal foi fundamental nos séculos XII e XIII.

A política seguida por D. Dinis e por D. Afonso IV, na primeira metade do século $\mathrm{XIV}$, a despeito de choques eventuais do último desses reis com a citada milícia foi de beneficiá-la, lançando uma forte ascendência sobre o seu funcionamento interno, sobre a nomeação de seus mestres e em situações excepcionais sobre o destino das igrejas herdadas pela nova Ordem. ${ }^{80}$

No contexto anterior a 1318-1319, no front interno do reino de Portugal, buscavase reforçar o quanto as terras da Ordem do Templo eram de alçada exclusiva do rei, logo, teriam sido apropriadas pela Ordem do Templo de forma abusiva. Tal como ressaltado nas inquirições de $1314^{81}$.

Evidentemente não é possível crer que uma Ordem tão poderosa quanto a do Templo tenha sido em algum momento tão inteiramente subordinada ao poder régio em Portugal conforme sugerido pelas cartas de sentença de 1308 e 1309 e pelas inquirições de 1314. Mas foi a junção entre um discurso para o plano mais local e regional - rei suserano dos bens da Ordem do Templo - com outro para o âmbito mais global da

concepção tradicional de potestas onde caberia ao Imperador e por extensão ao poder régio a incumbência de submisso a Deus a a S. Pedro assegurar a ordem interior, a paz, a proteger os clérigos, as igrejas e a cumprir a sua missão de salvação e de expansão do poder cristão. Afastando para longe a ameaça dos “ pagãos". A postura dos reis Ibéricos no processo de reconquista e na consequente reorganização da malha administrativa eclesiástica foi normalmente bastante ativa. Cf. FLORI, Jean. La guerre sainte. La formation de L'idée de croisade dans L'Occident Chrétien. Paris: Aubier,2001.

${ }^{79}$ Já no pontificado de Nicolau IV houve um esforço significativo por parte do papado em favorecer uma aliança Franco Castelhana em oposição as pretensões Aragonesas no mediterrâneo, de uma maneira geral e na Sicília em particular. Em concomitância com esse processo de favorecimento da coroa de Castela havia toda uma política de propiciar a união da cristandade em torno de uma cruzada mediterrânica e um dos principais instrumentos diplomáticos foi justamente o surgimento da idéia da realização de uma conferência mulitilateral em 1290 para pacificar os conflitos da Cristandade. O tratado de Taracón-Brignoles de 1291 foi concebido com passo prévio para uma nova cruzada para a terra santa, contudo as flutuações políticas no contexto da Cristandade e no contexto Ibérico dificultaram a realização desse propósito de pacificação. Cf. MARZAL, Miguel Angel. Op.cit.

${ }^{80}$ I.A.N./T.T, Gaveta III, maço 4, N. 12 \& Chancelaria de D. Dinis Livro 3, fl. 148v, 149. Em 18 de Janeiro de 1323 o rei D.Dinis doa à Ordem de Cristo as igrejas da vila de Soure que anteriormente haviam pertencido a Ordem do Templo. Na doação de D. Dinis à Ordem de Cristo o seu mestre se obrigava ao pagamento dos professores de leis e decretais, físicos, gramáticos e a dois conservadores.

${ }^{81}$ Podemos resumir as inquirições aos seguintes argumentos: 1. os bens da Ordem do Templo foram entregues como feudos; segundo alguns testemunhantes, o nível de interferência do rei na Ordem do Templo era tal, que não faziam capítulo sem sua ordem ou representante régio que convocasse e acompanhasse os trabalhos; em suma, devido a inúmeras questões a Ordem do Templo esteve inteiramente à mercê do poder régio desde a época do Conde D. Henrique e de seu filho Afonso Henriques, logo, era legítimo que o rei D. Dinis tomasse posse das vilas em questão .Cf. 1314, Março, Coimbra. I.A.N./T.T. Livro dos Mestrados, fls. 143v-146v; .1314, abril (?), Coimbra. I.A.N./T.T. Livro dos Mestrados, fls.146v148v; 1314, abril, Coimbra. I.A.N./T.T. Livro dos Mestrados, fls.146v-148v. 
Cristandade — rei potencial cruzado peninsular — , que explica parte do sucesso na tutela lançada pelo poder régio em Portugal sobre os bens da Ordem do Templo e na criação da nova Ordem Militar de Cristo. A não utilização indiscriminada da violência física ou do processo inquisitorial estrito-senso deveu-se muito mais a uma opção estratégica do que necessariamente a uma boa vontade inata do monarca ou da monarquia como um todo.

\section{Considerações finais}

Efetivamente para o período que se estende de 1307 a 1319, época de transição da Ordem do Templo para Ordem de Cristo a documentação subsistente é diminuta. E acreditamos que isso não é casual. A estratégia de construção de uma memória favorável a monarquia no contexto imediato da transição pode ter levado a simples supressão de documentos que poderiam, por sua vez, evidenciar a resistência dos freires da Ordem do Templo ou de escritos que não se coadunassem com a ideia de perfeita harmonia e subordinação dos templários à realeza. Nessa construção de memória, não era conveniente ressaltar que os templários eram culpados de sodomia e outras tantas práticas heréticas, afinal como alegar profunda proximidade com a Ordem se fosse constatado que essa era maléfica? Isso comprometia a estratégia escolhida pelo rei e seu ciclo mais imediato.

Por outro lado, a alegação de que os bens do Templo eram essenciais para a defesa do reino contra os muçulmanos - em um reino que assumia implicitamente seu papel de reino cruzado - era um argumento que encontrou ressonância na corte pontifícia, tendo em vista o pano de fundo da luta pelo controle dos estreitos por parte de Castela ou mesmo as ressonâncias da queda da Terra Santa, em 1291, que colocavam a luta contra os muçulmanos em evidência, tanto entre as camadas populares quanto na diplomacia pontifícia.

A articulação entre os dois planos de argumentação permitiu sustentar a legitimidade de uma ação que claramente feriu os privilégios eclesiásticos que foram oferecidos à Ordem do Templo pelo papado aos longos dos séculos XII e XIII. A conjunção dos dois conjuntos de argumentos suavizava o impacto de uma atitude que era potencialmente explosiva, levando em conta os afrontamentos entre bispos e poder régio ao longo de boa parte do século XIII. O sucesso posterior da relação entre Ordem de 
Revista Signum, 2017, vol. 18, n. 1.

Cristo e a monarquia oblitera as dissonâncias entre o poder real e o passado templário.

Sobre certo ponto de vista ao ressaltar as continuidades entre uma Ordem e outra corremos o risco de nos colocar como simples tributários de uma complexa operação de construção de memória que teve no período dionisino seus primeiros passos. 